\title{
GROUNDWATER QUALITY ASSESSMENT FOR DRINKING PURPOSE IN BAUND BLOCK, CHARKHI DADRI DISTRICT, HARYANA
}

\author{
Anup Kumar ${ }^{1 *}$, Himanshu², Satish Kumar ${ }^{2}$ and V.S.Arya ${ }^{3}$ \\ ${ }^{1,3}$ Haryana Space Applications Centre (HARSAC), Hisar \\ ${ }^{2}$ Department of Geology, Kurukshetra University, Kurukshetra
}

\section{Research Article}

Received: 30.10.2021

Accepted: 15.11.2021

Published: 25.11.2021

\begin{abstract}
Water is important for survival of life on the planet Earth. In the present developmental activities water is excessively used in agriculture, industries, drinking and daily house hold activities. These has resulted in declining of groundwater depth and deterioration of groundwater quality. In the present study groundwater quality for drinking purpose has been assessed in Baund block of Charkhi Dadri district of Haryana. In the present study twelve groundwater samples were collected during field visit in the study area in double capped $250 \mathrm{ml}$ plastic bottles and sample locations were taken with the help of mobile GPS. Groundwater samples were analyzed using Field Water Testing Kit prepared by Tamil Nadu Water Supply and Drainage (TWAD) Board, Chennai for twelve chemical parameters-pH, alkalinity, hardness, chloride, total dissolved solids (TDS), fluoride, iron, ammonia, nitrite, nitrate, phosphate, residual chlorine. Results of chemical analysis were entered in excel software and prepared bar graphs. Result of chemical analysis of groundwater samples were compared with BIS (IS 10500:2012) drinking water standards for drinking purpose. The study shows that $\mathrm{pH}$ ranges 6.5 to 7.5 , alkalinity $150 \mathrm{mg} / \mathrm{l}$ to $550 \mathrm{mg} / \mathrm{l}$, hardness $150 \mathrm{mg} / \mathrm{l}$ to $800 \mathrm{mg} / \mathrm{l}$, chloride $50 \mathrm{mg} / \mathrm{l}$ to $1200 \mathrm{mg} / \mathrm{l}$, TDS 600 $\mathrm{mg} / \mathrm{l}$ to $2964 \mathrm{mg} / \mathrm{l}$, iron nil to $3 \mathrm{mg} / \mathrm{l}$, ammonia nil to $5 \mathrm{mg} / \mathrm{l}$, nitrite $0.2 \mathrm{mg} / \mathrm{l}$ to $1 \mathrm{mg} / \mathrm{l}$, nitrate $45 \mathrm{mg} / \mathrm{l}$ to $100 \mathrm{mg} / \mathrm{l}$, phosphate nil in all the twelve groundwater samples and residual chlorine nil to $0.2 \mathrm{mg} / \mathrm{l}$. The study is highly useful for planning and monitoring of groundwater quality for drinking purpose in the study area.
\end{abstract}

Keywords: Groundwater, quality, drinking, Baund, Charkhi Dadri, Haryana.

\section{INTRODUCTION}

Water is important for living beings for survival. In the present context of increasing population, industrial setups and agriculture practices demand of water is increasing many folds. Need of the hour is to make a balance between the availability and demand of water for each user sectors based on priority. The utmost priority of water is for drinking purpose and households needs after agriculture and industrial requirement. Good quality water plays vital role for drinking and other household activities. Singh and Kumar (2014), Annapoorna and Janardhana (2015), Punia et al. (2015), Choudhary et al. (2016), Nelly and Mutua (2016), Kaur et al. (2017), Khan and Jhariya (2017),
Lalitha et al. (2017), Madhav et al.(2018), Mohamad (2019), Molekoa et al. (2019) studied the groundwater quality for drinking purpose in different area.

\section{STUDY AREA}

Baund block is falling in Charkhi Dadri district of Haryana (Fig.1). The geo-coordinates of the study area are latitudes $28.63^{\circ} \mathrm{N}$ to $28.82^{\circ} \mathrm{N}$ and longitudes $76.23^{\circ} \mathrm{E}$ to $76.41^{\circ} \mathrm{E}$ and covers an area of 234.40 sq. $\mathrm{km}$. The study area falls in semi-arid type of climate. Geologically, the area has alluvium and blown sand of Quaternary age and geomorphologically alluvial plain and aeolian plain. 


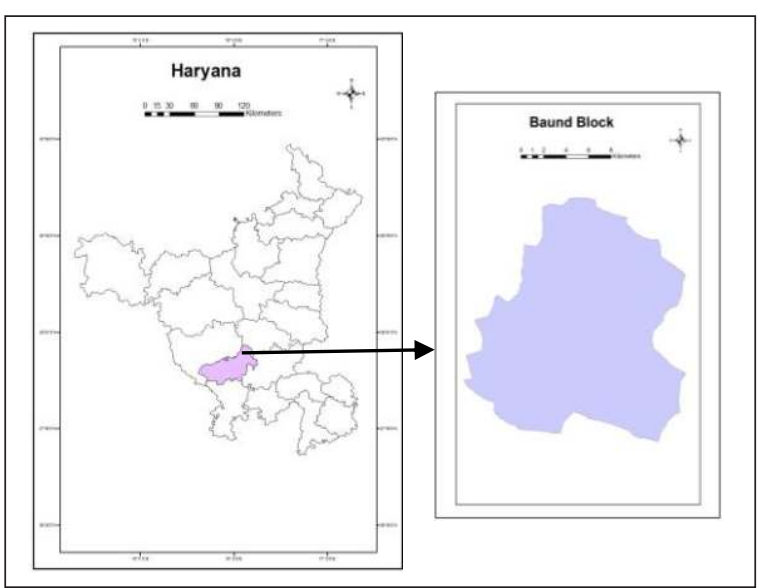

Fig.1: Location map of the study area.

\section{OBJECTIVE}

The main objective was to assessment of groundwater quality for drinking purpose in the study area.

\section{MATERIALSAND METHODOLOGY}

In the study area twelve groundwater samples were collected during the field visit and geo-coordinates of sample locations were taken with the help of mobile GPS. The groundwater samples were collected in double capped $250 \mathrm{ml}$ plastic bottles from hand pump (HP), tube well (TW), dug well (DW) and labeled sample number and name of the location. Groundwater samples were analyzed using Field Water Testing Kit prepared by Tamil Nadu Water Supply and Drainage (TWAD) Board, Chennai for twelve chemical parameters-pH, alkalinity, hardness, chloride, total dissolved solids (TDS), fluoride, iron, ammonia, nitrite, nitrate, phosphate, residual chlorine (Table 1). Results of chemical analysis were entered in excel software and prepared bar graphs. Result of chemical analysis of groundwater samples were compared with BIS (IS 10500:2012) drinking water standards (Table 2) for drinking purpose of groundwater in the study area.

Table 1: Results of groundwater samples analysis in the study area.

\begin{tabular}{|c|c|c|c|c|c|c|c|c|c|c|c|c|c|c|c|c|}
\hline $\begin{array}{l}\text { S. } \\
\text { No. }\end{array}$ & Location & Latitude & $\begin{array}{l}\text { Longi- } \\
\text { tude }\end{array}$ & Source & $\mathrm{pH}$ & $\begin{array}{c}\text { Alkal- } \\
\text { inity } \\
(\mathrm{mg} / \mathrm{l})\end{array}$ & $\begin{array}{c}\text { Hard } \\
\text { ness } \\
(\mathrm{mg} / \mathrm{l})\end{array}$ & $\begin{array}{l}\text { Chlo- } \\
\text { ride }\end{array}$ & TDS & $\begin{array}{l}\text { Fluo- } \\
\text { ride } \\
(\mathrm{mg} / \mathrm{l})\end{array}$ & $\begin{array}{l}\text { Iron } \\
(\mathrm{mg} / \mathrm{l})\end{array}$ & $\begin{array}{c}\text { Amm- } \\
\text { onia } \\
(\mathrm{mg} / \mathrm{l})\end{array}$ & $\begin{array}{c}\text { Nitrite } \\
(\mathrm{mg} / \mathrm{l})\end{array}$ & $\begin{array}{c}\text { Nitrate } \\
(\mathrm{mg} / \mathrm{l})\end{array}$ & $\begin{array}{l}\text { Phos } \\
\text { phate } \\
(\mathrm{mg} / \mathrm{l})\end{array}$ & $\begin{array}{c}\text { Residual } \\
\text { Chlorine } \\
\text { (mg/l) }\end{array}$ \\
\hline 1. & Sauf-Kasni & 28.67 & 76.24 & HP & 7 & 200 & 250 & 50 & 600 & 0.5 & 0 & 0 & 0.5 & 75 & 0 & 0 \\
\hline 2. & Misri & 28.66 & 76.28 & HP & 7.5 & 460 & 800 & 1200 & 2952 & 1 & 1 & 1 & 0.5 & 75 & 0 & 0 \\
\hline 3. & Sanwar & 28.70 & 76.29 & $\mathrm{HP}$ & 7 & 150 & 450 & 250 & 1020 & 3 & 0 & 0.5 & 0.5 & 100 & 0 & 0 \\
\hline 4. & Ranilla & 28.70 & 76.35 & $\mathrm{HP}$ & 7.5 & 260 & 800 & 300 & 1632 & 5 & 0 & 1 & 1 & 75 & 0 & 0 \\
\hline 5. & Bhageswari & 28.67 & 76.35 & TW1 & 7.5 & 430 & 320 & 250 & 1200 & 5 & 0 & 0.5 & 0.5 & 75 & 0 & 0 \\
\hline 6. & Achina & 28.65 & 76.36 & DW & 7 & 230 & 350 & 50 & 756 & 1.5 & 3 & 0.5 & 0.5 & 45 & 0 & 0 \\
\hline 7. & Sanjarwas & 28.72 & 76.31 & HP & 7 & 300 & 200 & 330 & 996 & 5 & 0 & 0.5 & 0.5 & 75 & 0 & 0 \\
\hline 8. & Sankror & 28.75 & 76.27 & HP & 7 & 330 & 150 & 70 & 660 & 5 & 0 & 0.5 & 0.2 & 45 & 0 & 0 \\
\hline 9. & Baund & 28.78 & 76.33 & HP & 6.5 & 180 & 400 & 100 & 816 & 1.5 & 0 & 0.5 & 0.5 & 100 & 0 & 0 \\
\hline 10. & Baund Khurd & 28.77 & 76.33 & HP & 7 & 550 & 800 & 1120 & 2964 & 0 & 0 & 5 & 0.5 & 45 & 0 & 0.2 \\
\hline 11. & Unn & 28.76 & 76.37 & HP & 7.5 & 300 & 400 & 120 & 984 & 5 & 0 & 1 & 0.5 & 75 & 0 & 0.2 \\
\hline 12. & Malkos & 28.78 & 76.31 & DW & 7.5 & 400 & 400 & 190 & 1188 & 5 & 0 & 0 & 0.5 & 75 & 0 & 0.2 \\
\hline
\end{tabular}

Table 2: Drinking water standards (IS 10500:2012).

\begin{tabular}{|l|l|c|c|c|}
\hline \multirow{2}{*}{ S. No. } & \multirow{2}{*}{ Parameter } & \multicolumn{2}{|c|}{ Potable } & \multirow{2}{*}{ Non-Potable } \\
\cline { 3 - 4 } & & Desirable & Permissible & \\
\hline 1 & $\mathrm{pH}$ & 6.5 to 8.5 & - & $<6.5$ and $>8.5$ \\
\hline 2 & Alkalinity (mg/l) & $<200$ & $200-600$ & $>600$ \\
\hline 3 & Total Hardness (mg/l) & $<200$ & $200-600$ & $>600$ \\
\hline 4 & Chloride (mg/l) & $<250$ & $250-1000$ & $>1000$ \\
\hline 5 & Total Dissolved Solids (TDS) (mg/l) & $<500$ & $500-2000$ & $>2000$ \\
\hline 6 & Fluoride (mg/l) & $<1.0$ & $1.0-1.5$ & $>1.5$ \\
\hline 7 & Iron (mg/l) & $<0.3$ & - & $>0.3$ \\
\hline
\end{tabular}




\begin{tabular}{|l|l|c|c|c|}
\hline 8 & Ammonia $(\mathrm{mg} / \mathrm{l})$ & $<0.5$ & - & $>0.5$ \\
\hline 9 & Nitrite $(\mathrm{mg} / \mathrm{l})$ & $<1.0$ & - & $>1.0$ \\
\hline 10 & Nitrate $(\mathrm{mg} / \mathrm{l})$ & $<45$ & - & $>45$ \\
\hline 11 & Phosphate $(\mathrm{mg} / \mathrm{l})$ & $<1.0$ & $0.2-1.0$ & $>1.0$ \\
\hline 12 & Residual Chlorine $(\mathrm{mg} / \mathrm{l})$ & $<0.2$ & $>1.0$ \\
\hline
\end{tabular}

\section{RESULTS AND DISCUSSION}

\section{i. $\mathbf{p H}$}

In the study area $\mathrm{pH}$ ranges 6.5 to 7.5 (Table 1, Fig.2). As per BIS (IS 10500:2012) drinking water standards $\mathrm{pH}$ is desirable 6.5-8.5 and non-potable $<6.5$ and $>8.5$ (Table 2). $\mathrm{pH}$ is desirable in all the twelve groundwater samples (Saunf-Kasni, Misri, Sanwar, Ranilla, Bhageswari, Achina, Sanjarwas, Sankror, Baund, Baund Khurd, Unn, Malkos).

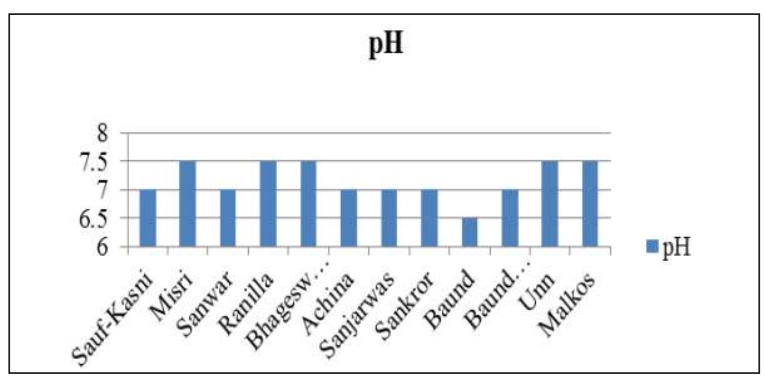

Fig. 2: pH in groundwater samples.

\section{ii. Alkalinity}

Alkalinity ranges $150 \mathrm{mg} / \mathrm{l}$ to $550 \mathrm{mg} / \mathrm{l}$ (Table 1, Fig.3) in the study area. As per BIS (IS 10500:2012) drinking water standards alkalinity is desirable $<200 \mathrm{mg} /$, permissible $200 \mathrm{mg} / \mathrm{l}-600 \mathrm{mg} / \mathrm{l}$ and non-potable $>600$ $\mathrm{mg} / \mathrm{l}$ (Table 2). Alkalinity is desirable in two groundwater samples (Sanwar, Baund) and permissible in ten groundwater samples (Saunf-Kasni, Misri, Ranilla, Bhageswari, Achina, Sanjarwas, Sankror, Baund Khurd,Unn, Malkos).

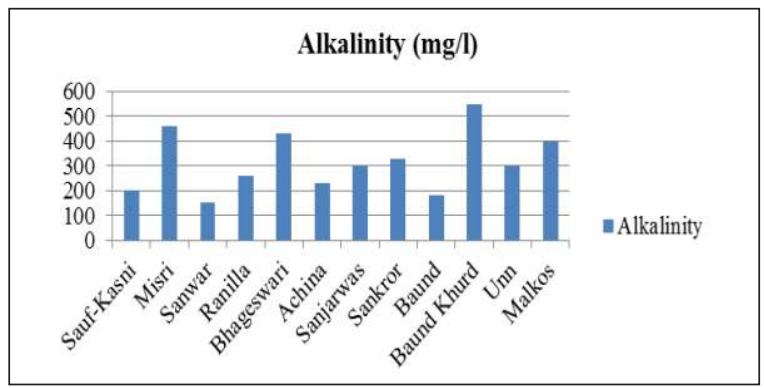

Fig. 3: Alkalinity in groundwater samples.

\section{iii. Hardness}

Hardness ranges $150 \mathrm{mg} / \mathrm{l}$ to $800 \mathrm{mg} / \mathrm{l}$ (Table 1, Fig.4) in the study area. As per BIS (IS 10500:2012) drinking water standards hardness is desirable $<200 \mathrm{mg} / \mathrm{l}$, permissible $200 \mathrm{mg} / \mathrm{l}-600 \mathrm{mg} / \mathrm{l}$ and non-potable $>600$ $\mathrm{mg} / \mathrm{l}$ (Table 2). Hardness is desirable in one groundwater sample (Sankror), permissible in nine groundwater samples (Saunf-Kasni, Sanwar, Bhageswari,Achina, Sanjarwas, Baund, Unn, Malkos) and non-potable in three groundwater samples (Misri, Ranilla, Baund Khurd).

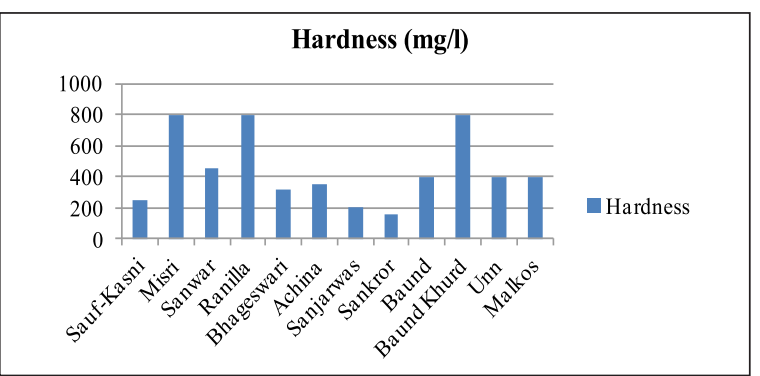

Fig. 4: Hardness in groundwater samples.

\section{iv. Chloride}

In the study area chloride ranges $50 \mathrm{mg} / \mathrm{l}$ to $1200 \mathrm{mg} / \mathrm{l}$ (Table 1, Fig.5). As per BIS (IS 10500:2012) drinking water standards chloride is desirable $<250 \mathrm{mg} / \mathrm{l}$, permissible $250 \mathrm{mg} / \mathrm{l}-1000 \mathrm{mg} / \mathrm{l}$ and non-potable $>1000 \mathrm{mg} / \mathrm{l}$ (Table 2). Chloride is desirable in six groundwater samples (Saunf-Kasni, Achina, Sankror, Baund, Unn,Malkos), permissible in four groundwater samples (Sanwar, Ranilla, Bhageswari, Sanjarwas) and non-potable in two groundwater samples (Misri, Baund Khurd).

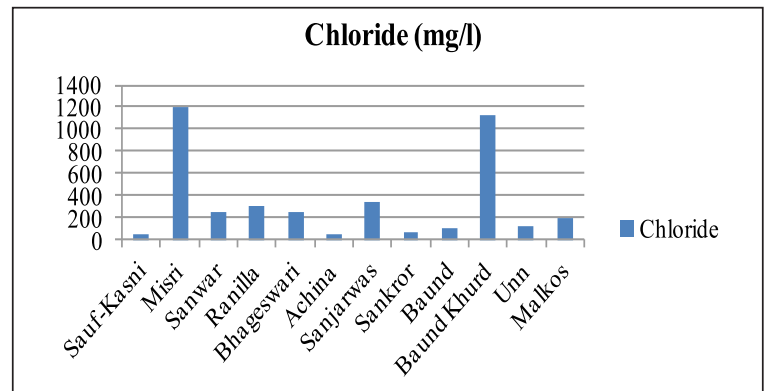

Fig. 5: Chloride in groundwater samples. 


\section{v. Total Dissolved Solids (TDS)}

TDS ranges $600 \mathrm{mg} / \mathrm{l}$ to $2964 \mathrm{mg} / \mathrm{l}$ (Table 1, Fig.6) in the study area. As per BIS (IS 10500:2012) drinking water standards TDS is desirable $<500 \mathrm{mg} / \mathrm{l}$, permissible $500 \mathrm{mg} / \mathrm{l}$ - $2000 \mathrm{mg} / \mathrm{l}$ and non-potable $>2000 \mathrm{mg} / \mathrm{l}$ (Table 2). TDS is permissible in ten groundwater samples (Saunf-Kasni, Sanwar, Ranilla, Bhageswari, Achina, Sankror, Sanjarwas, Baund, Unn,Malkos) and non-potable in two groundwater samples (Misri, Baund Khurd).

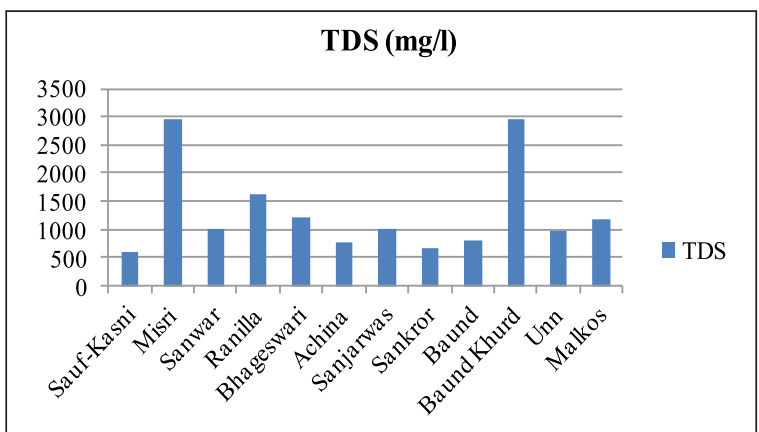

Fig. 6: TDS in groundwater samples

\section{vi. Fluoride}

In the study area fluoride ranges nil to $5 \mathrm{mg} / \mathrm{l}$ (Table 1, Fig.7). As per BIS (IS 10500:2012) drinking water standards fluoride is desirable $<1.0 \mathrm{mg} / \mathrm{l}$, permissible $1.0 \mathrm{mg} / \mathrm{l}-1.5 \mathrm{mg} / \mathrm{l}$ and non-potable $>1.5 \mathrm{mg} / \mathrm{l}$ (Table 2). Fluoride is desirable in two groundwater samples (Saunf-Kasni, Baund Khurd), permissible in three groundwater samples (Misri, Achina, Baund) and nonpotable in seven groundwater samples (Sanwar, Ranilla, Bhageswari, Sankror, Sanjarwas, Unn, Malkos).

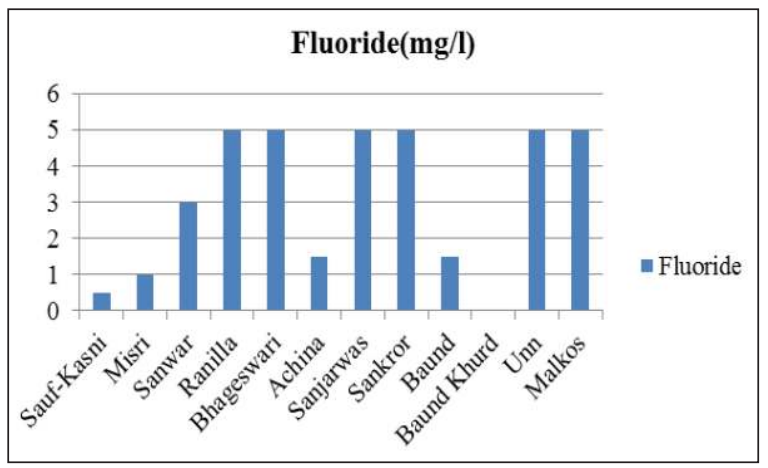

Fig.7: Fluoride in groundwater samples.

vii. Iron

In the study area iron ranges nil to $3 \mathrm{mg} / \mathrm{l}$ (Table 1 , Fig.8). As per BIS (IS 10500:2012) drinking water standards iron is desirable $<0.3 \mathrm{mg} / \mathrm{l}$ and non-potable $>0.3 \mathrm{mg} / \mathrm{l}$ (Table 2). Iron is desirable in ten groundwater samples (Saunf-Kasni, Sanwar, Ranilla, Bhageswari, Sankror, Sanjarwas, Baund, Baund Khurd, Unn,Malkos) and non-potable in two groundwater samples (Misri, Achina).

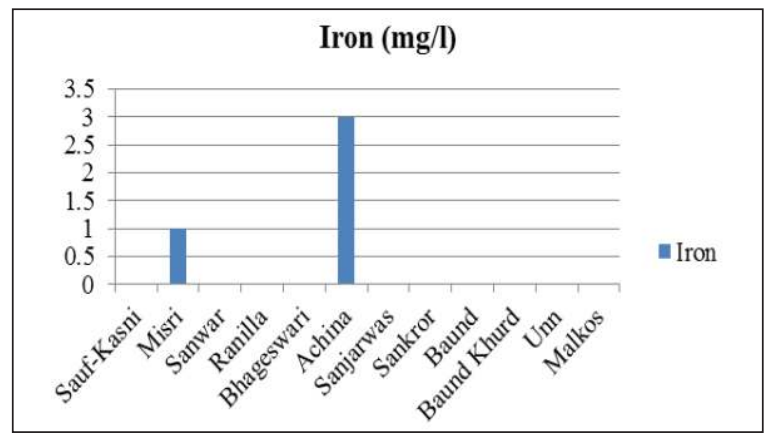

Fig. 8: Iron in groundwater samples.

\section{viii. Ammonia}

Ammonia ranges nil to $5 \mathrm{mg} / \mathrm{l}$ (Table 1, Fig.9) in the study area. As per BIS (IS 10500:2012) drinking water standards ammonia is desirable $<0.5 \mathrm{mg} / \mathrm{l}$ and nonpotable $>0.5 \mathrm{mg} / \mathrm{l}$ (Table 2). Ammonia is desirable in eight groundwater samples (Saunf-Kasni, Sanwar, Achina, Bhageswari, Sankror, Sanjarwas, Baund, Malkos) and non-potable in four groundwater samples (Misri, Ranilla, Baund Khurd, Unn).

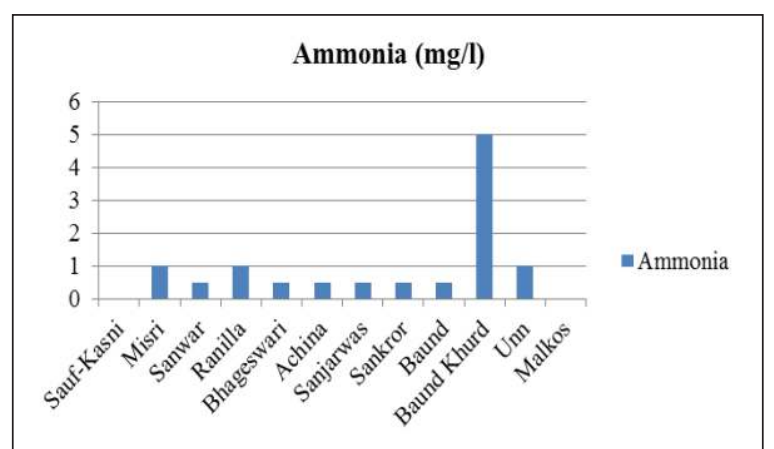

Fig.9: Ammonia in groundwater samples.

\section{ix. Nitrite}

In the study area nitrite ranges $0.2 \mathrm{mg} / \mathrm{l}$ to $1 \mathrm{mg} / \mathrm{l}$ (Table 1, Fig.10). As per BIS (IS 10500:2012) drinking water standards ammonia is desirable $<1 \mathrm{mg} / \mathrm{l}$ and nonpotable $>1 \mathrm{mg} / \mathrm{l}$ (Table 2). Nitrite is desirable in all the twelve groundwater samples (Saunf-Kasni, Sanwar, Achina, Bhageswari, Sankror, Sanjarwas, Baund, Misri, Ranilla, Baund Khurd, Unn, Malkos).

\section{x. Nitrate}

In the study area nitrate ranges $45 \mathrm{mg} / \mathrm{l}$ to $100 \mathrm{mg} / \mathrm{l}$ (Table 1, Fig.11). As per BIS (IS 10500:2012) drinking water standards nitrate is desirable $<45 \mathrm{mg} / \mathrm{l}$ and nonpotable $>45 \mathrm{mg} / \mathrm{l}$ (Table 2 ). Nitrate is desirable in three 


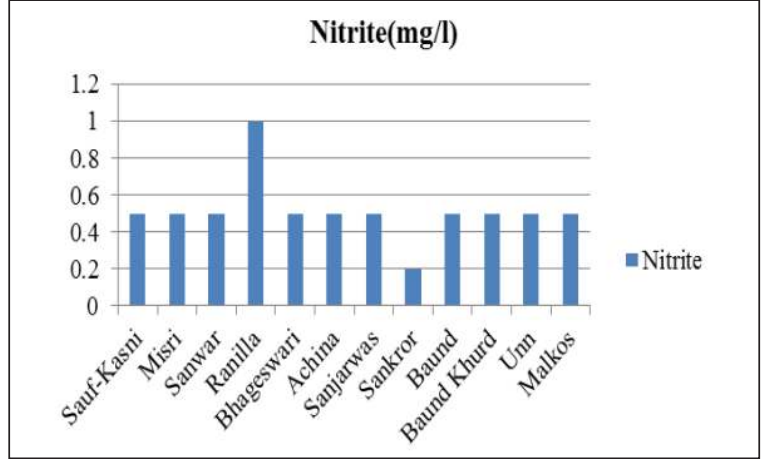

Fig.10: Nitrite in groundwater samples.

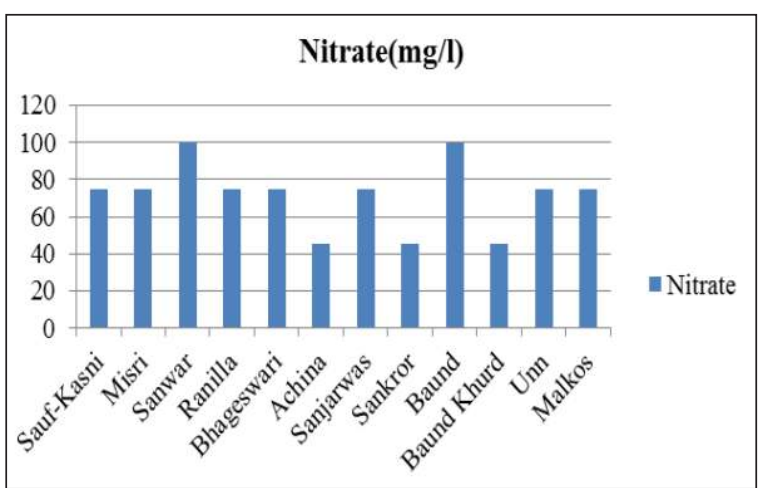

Fig.11: Nitrate in groundwater samples.

groundwater samples (Achina, Sankror, Baund Khurd) and non-potable in nine groundwater samples (SaunfKasni, Sanwar, Bhageswari, Sanjarwas, Baund,Misri, Ranilla, Unn, Malkos).

\section{xi. Phosphate}

Phosphate is nil in all the twelve groundwater samples (Table 1, Fig.12) in the study area. As per BIS (IS 10500:2012) drinking water standards phosphate is desirable $<1.0 \mathrm{mg} / \mathrm{l}$ and non-potable $>1.0 \mathrm{mg} / \mathrm{l}$ (Table 2). Phosphate is desirable in all the twelve groundwater samples (Saunf-Kasni, Sanwar, Achina, Bhageswari, Sankror, Sanjarwas, Baund,Misri, Ranilla, Baund Khurd, Unn, Malkos).

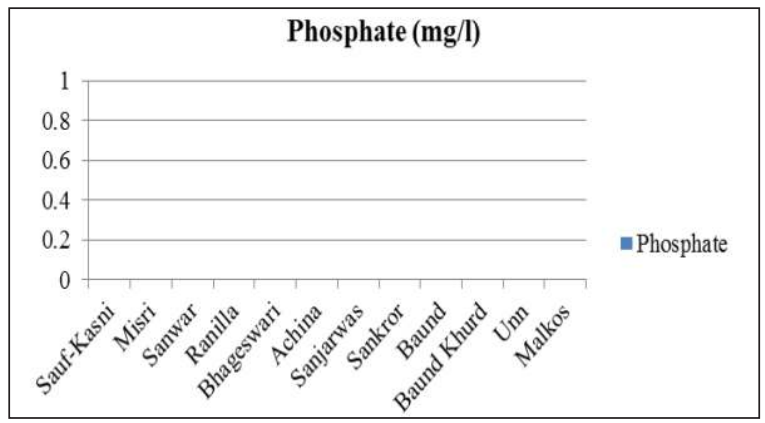

Fig.12: Phosphate in groundwater samples.

\section{xii. Residual Chlorine}

In the study area residual chlorine ranges nil to $0.2 \mathrm{mg} / \mathrm{l}$ (Table 1, Fig.13). As per BIS (IS 10500:2012) drinking water standards residual chlorine is desirable $<0.2$ $\mathrm{mg} / \mathrm{l}$, permissible $0.2 \mathrm{mg} / \mathrm{l}-1.0 \mathrm{mg} / \mathrm{l}$ and non-potable $>1.0 \mathrm{mg} / \mathrm{l}$ (Table 2). Residual Chlorine is desirable in nine groundwater samples (Saunf-Kasni, Sanwar, Achina, Bhageswari, Sankror, Sanjarwas, Baund,Misri, Ranilla) and permissible in three groundwater samples (Baund Khurd, Unn, Malkos).

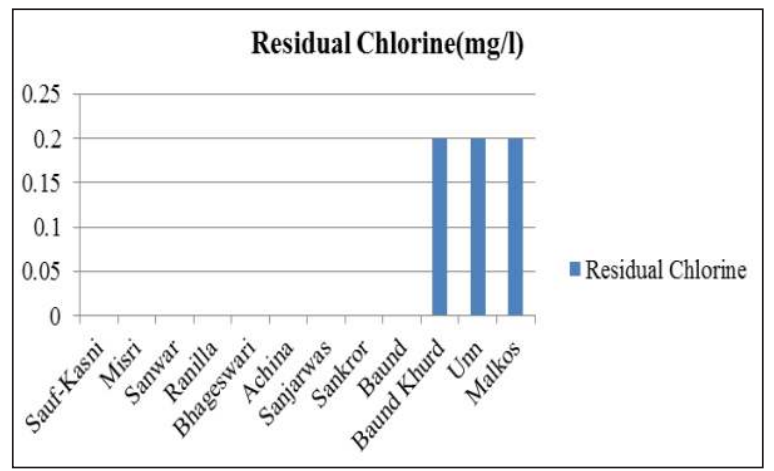

Fig.13: Residual Chlorine in groundwater samples.

\section{CONCLUSIONS}

In the study area $\mathrm{pH}$, nitrite and phosphate is desirable in all the twelve groundwater samples. Alkalinity is desirable in two groundwater samples and permissible in ten groundwater samples. Hardness is desirable in one groundwater sample, permissible in nine groundwater samples and non-potable in three groundwater samples. Chloride is desirable in six groundwater samples, permissible in four groundwater samples and non-potable in two groundwater samples. TDS is permissible in ten groundwater samples and non-potable in two groundwater samples. Fluoride is desirable in two groundwater samples, permissible in three groundwater samples and non-potable in seven groundwater samples. Iron is desirable in ten groundwater samples and non-potable in two groundwater samples. Ammonia is desirable in eight groundwater samples and non-potable in four groundwater samples. Nitrate is desirable in three groundwater samples and non-potable in nine groundwater samples. Residual Chlorine is desirable in nine groundwater samples and permissible in three groundwater samples. The study is highly useful for planning and monitoring of groundwater quality for drinking purpose in the study area.

\section{REFERENCES}

1. Annapoorna, H. and Janardhana, M.R. (2015): Assessment of groundwater quality for drinking 
purpose in rural areas surrounding a defunct copper mine, Aquatic Procedia, 4:685-692.

2. Choudhary, Shabya, Ramteke, Shobhana, Rajhans, Keshaw Prakash, Sahu, Pravin Kumar, Chakradhari, Suryakant, Patel, Khageshwar Singh, Matini, Laurent (2016): Assessment of groundwater quality in Central India, Journal of Water Resource and Protection, 8:12-19.

3. Kaur, Tajinder, Bhardwaj, Renu, Arora, Saroj (2017): Assessment of groundwater quality for drinking and irrigation purposes using hydrochemical studies in Malwa region, southwestern part of Punjab, India, Applied Water Science, 7:3301-3316.

4. Khan, Rubia and Jhariya, D. C. (2017): Groundwater quality assessment for drinking purpose in Raipur City, Chhattisgarh using water quality index and geographic information system, Journal Geological Society of India, 90:69-76.

5. Lalitha, B.,Vijaya, , Tejaswini, K., Sai (2017): A study on assessment of groundwater quality and its suitability for drinking in Vuyyuru, Krishna(dist.), Andhra Pradesh, International Journal of Engineering Development and Research, 5 (20):1662-1668.

6. Madhav, Sughosh, Ahamad, Arif, Kumar, Ashutosh, Kushawaha, Jyoti, Singh, Pardeep and Mishra, P. K. (2018): Geochemical assessment of groundwater quality for its suitability for drinking and irrigation purpose in rural areas of Sant Ravidas Nagar (Bhadohi), Uttar Pradesh, Geology, Ecology, and Landscapes, 2 (2):127-136.

7. Mohamad Najib Ibrahim (2019): Assessing groundwater quality for drinking purpose in Jordan: application of water quality index, Journal of Ecological Engineering, 20 (3):101-111.

8. Molekoa, Mmasabata Dolly, Avtar, Ram, Kumar, Pankaj, MinhHuynh Vuong Thu and Tonni Kurniawan, Agustiono (2019): Hydrogeochemical assessment of groundwater quality of Mokopane area, Limpopo, South Africa using statistical approach, Water, 11(1891):1-18.

9. Nelly, Kiplangat, C. and Mutua, Felix (2016): Groundwater quality assessment using GIS and remote sensing- a case study of Juja location, Kenya, American Journal of Geographic Information System, 5(1):12-23.

10. Punia, Sunita, Duddi, S. and Anju, M. (2015): Hydrochemistry and water quality assessment on groundwater of Bhiwani District, Haryana, India, Pollution Research, 34 (3):21-32.

11. Singh, S. K. and Kumar, L. (2014): Characterization of rural drinking water sources in Bhiwani district, Haryana, International Journal of Interdisciplinary Research and Innovations, 2 (4):27-37. 